\title{
Existing Local Ecolinguistic Study for Exposure of Exotic Fish Type on Tourism Point in Bunaken Island the Province of North
}

\author{
Mirjam Tenda* \\ Manado State Polytechnic \\ Manado, Indonesia \\ *mirjamtenda68@gmail.com
}

\begin{abstract}
Bunaken National Marine Park was designated as a National Park in 1991 by the Minister of for the purpose of preserving it toward the disastrous and irresponsible act of human being. Prior to this, a group of divers in 1975, had discovered this beautiful undersea garden and had started to invite guests and tourists to come and visit it. Recently, the growing number of tourist's arrival to the park in the last five years have provided significant impacts to the local economy. Charter flights from China with a 200 seats available have created new markets for this park. However, this positive growth is also accompanied by the negative impacts of tourism to the environment, the local culture and the language of the community. The latest development in the local language, for example, has been critical. Due to the increase use of foreign language, the local language has almost lost its significance. The gradual decline in the use of local language will threaten the existence of the language. The local community is entitled to pass the language through oral and written expression and the decrease use of the local language in the current communication is significant. The research with eco linguistic approach was conducted in Bunaken National Park aimed at providing exotic and appealing fish inventory for tourists. A qualitative and quantitative research are employed to collect data using a set of closed and open questions to potential tourists in Bunaken National Marine Park. The answers are analyzed using tabular form.
\end{abstract} park

Keywords—eco linguistic; local language; exotic fish; marine

\section{INTRODUCTION}

Languages and environment are two inseparable parts and interconnected linked to each other. Through language, a certain environment is displayed. The Sapir [1] states that language refers to the physical and social environment which includes the sound and the meaning of the word. Sapir specifically explains that language and environment are displayed in the vocabulary. Haugen in Peter [2] perceives language ecology as a relation between language and environment. Fill in Lindo \& Bundsgaard (eds.) emphasize the significance eco linguistics as an interaction between language and its environment [3].

Bunaken National Park as an environment has its own language. As a national marine park, Bunaken was designated as conservation area through the decision of the Ministry of Forestry no. 730 / KPTS-11/1991 On October 15, 1991. Bunaken National Park covers an area of 89,065 Ha. And located along the southern coast of Bunaken Island $\left(0^{\circ} 35^{`} 00^{\prime \prime}\right.$ $\mathrm{LU})$, along the western coast of Manado Tua (124 59 00 ") and along beach east of Nain Island (124 50` 00 "east).

According to the data from North Sulawesi Provincial BPS 2016, foreign tourist arrivals to North Sulawesi has reached its peak in August with the number of foreign tourists as many as 7,904 visitors, of which 19.46 percent are foreign tourists. The second highest arrivals is in July with the number of tourists of 7,677 of which 18, 90 percent are foreign tourists. 81.64 percent of total foreign tourists are coming from China. The increase number of charter flights from China has greatly contributed to large share of Chinese' tourists to the number of total tourists. The increase intensity of contacts between local people and foreign tourist have significantly decrease the likely use of local language in the communication. The following figure shows the increase of tourist arrival in Manado

North Sulawesi Statistic number of tourist arrival:

$$
\begin{aligned}
& 2013=19.917 \\
& 2014=17.279 \\
& 2015=19.465 \\
& 2016=40.624 \\
& 2017=79.377
\end{aligned}
$$

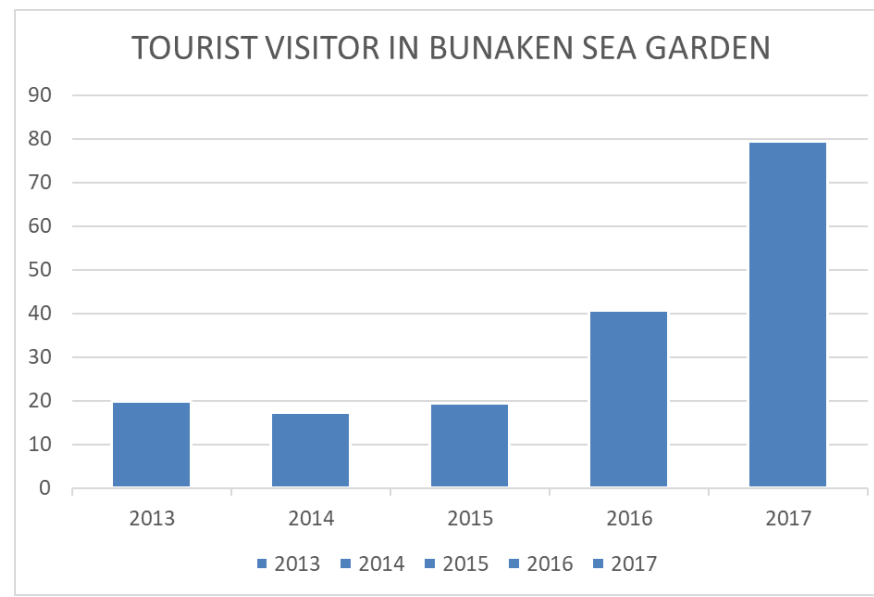

Fig 1. The growth of tourist in the last five years.

Bunaken national Marine Park has been heavily visited by the great number of foreign tourist. This fact exposes a critical 
threat to the continuation of the local language. There is a danger that the local community might lose its language fabrics. The presence of tour guide, divers, and operators are increasingly higher and the use of English as a means of communication has been intense. Without conscious effort to prevent this destructive environment, local language will gradually diminish from the social fabric of the local community. The common fact can be seen is in the lack of the local language knowledge in the communication context. The language chosen to be researched deals with exotic fishes.

A. The Purpose of This Study:

- To provide inventories of exotic and interesting fishes for tourists at diving spots on Bunaken Island.

- To identify the local language for exotic fish species that appeal to tourists on Bunaken Island.

\section{B. The Benefits of This Research are:}

- Provide information on the name of certain exotic fishes that are mostly attracted to tourist and their relevant local language.

- To ensure the preservation and sustainability of the local language in naming the fishes of the local environment.

- To ensure the development of local language and promote the sense of ownership in the local language.

\section{LITERATURE REVIEW}

\section{A. Eco-linguistic}

The language ecology according to Haugen, is the Language Ecology may be defined as the study of interactions between any given language and its environment [2]. Ecology Language can be defined as the study of inter-language interaction with the environment.

Eco linguistics theory explains the naming of things in relation to its eco linguistics environment. There are several ways on naming 'things'. Leech [4] distinguishes seven types of meaning: (1) conceptual meaning, (2) connotative meaning, (3) stylistic meaning (4) affective meaning, (5) reflective meaning, (6) colloquial meaning and (7) thematic meanings. While lexical is an elective form that is derived from the nominal form lexicon (vocabulary, vocabulary, vocabulary). Thus the unit of the lexicon is the lexeme, meaning the meaningful unit of language from the meaningful unit that the writer will form an exotic and interesting fish lexicon of its naming at the dive spots in the Bunaken national park which is the focus of the author's research.

\section{RESEARCH METHODOLOGY}

\section{A. Data Collection Design and Techniques}

The study was conducted in Bunaken Island, which has 17 dive sites on the coral reef ecosystem. Representation of data collection is determined based on the high frequency and number of tourist visits on the tourism attractions. The target of data collection is observation of various exotic biota that attract tourists on coral reef ecosystem in Bunaken Island. This preliminary observation was conducted by visualizing the existence of interesting marine biota available in Bunaken Island using direct survey of underwater area with the assistance facilitated by scientific identification [5]. As the complimentary references, the following authors and books are also included such as Myers [6], Allen [7], Lieske and Myers [8] and other complementary books.

Preliminary data retrieval is done through direct interviews of 100 respondents, especially divers and recreational tourists in the Island of Bunaken. This interview was focused on identifying any biota (international naming - popular name and scientific naming - Latin name) that are attractive to the respondents and are available at dive sites.

Based on the initial stages, the data is tabulated and packaged in the form of images in print (laminating) for the purposes of further data collection. The second data collection is interviewing and confirming at least 100 respondents from local residents in Bunaken Island to trace the use and knowledge of the respondent's local language concerning the relevant biota.

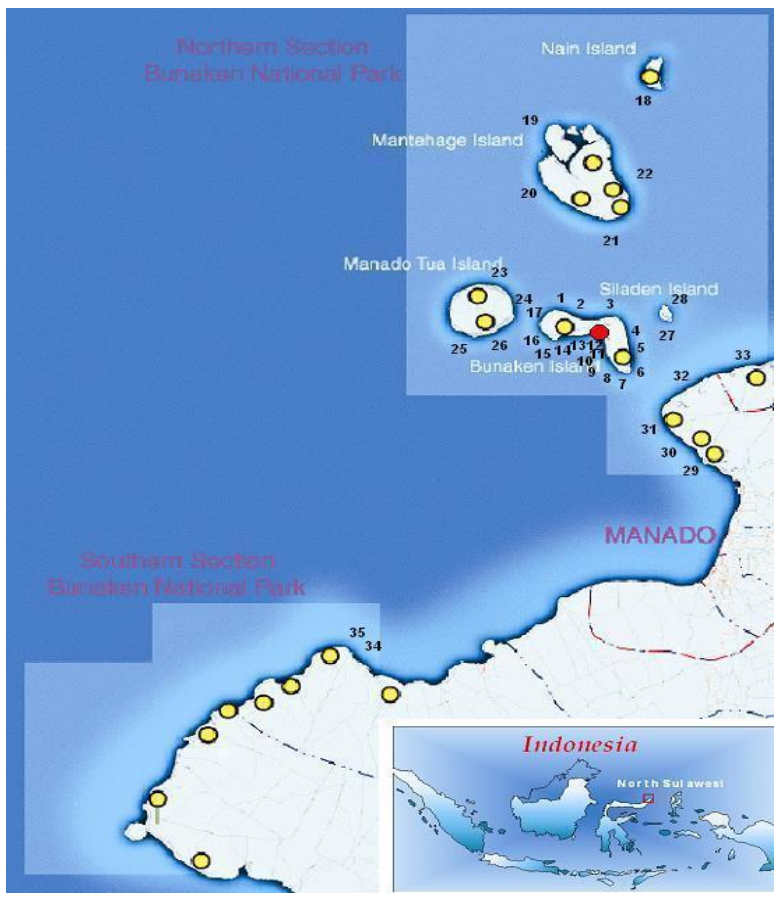

Fig 2. Map of research locations and 17 diving points on Bunaken Island.

\section{B. Data Analysis}

Reef fish is a kind of fish whose habitat living around coral or stay in the coral. Coral fish has the nature of silence in the reef and surrounding reefs. Coral fish consume algae that is surround the coral or polyps that live in the coral. There is also predator that eat little fish. Based on the results of the interviews, the data analysis was done through descriptive and figurative visual such as drawings, graphs and tables to determine the compositional naming of interesting biota with linguistic popular (English), scientific (Latin) and local languages.

Research is conducted with survey methods and interviews. Data is derived from differentiation of 2 (two) major sections 
of primary and secondary data. The primary data is data taken directly at the location of research. Whereas the data collected from the writings, the results of the research or the publications relating to the research are carried out. The procedure for collecting data in the research can be explained as follows. Secondary data retrieval: a study using an auxiliary tool such as a tape recorder, altogether has been composed in the list of questions / questionnaires for respondents. The questionnaires used for their properties and their materials relate to the research object of the intended purpose in which the respondents are free to answer according to their knowledge.

\section{Methods}

Based on the preliminary stages the data is tabulated and packaged in the form of laminated images for further data storage purposes. The second data collection is by interviewing and confirming at least 100 respondents from the local population on Bunaken Island to track the use and knowledge of the respondent's local language about the interesting biota or fish that became the focus of researchers.

\section{RESULTS AND DISCUSSION}

Based on the results of interviews, the data analysis is done descriptively through drawings, graphs and tables to determine the composition of the naming of exotic and interesting fish species with naming theory and generative theory of words in scientific (Latin) and local languages.

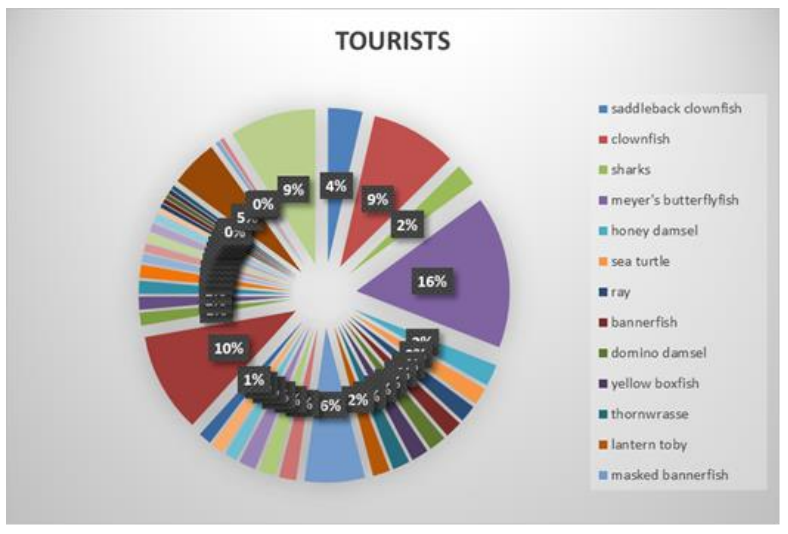

Fig 3. Chart of exotic fish percentage preferred by tourists.

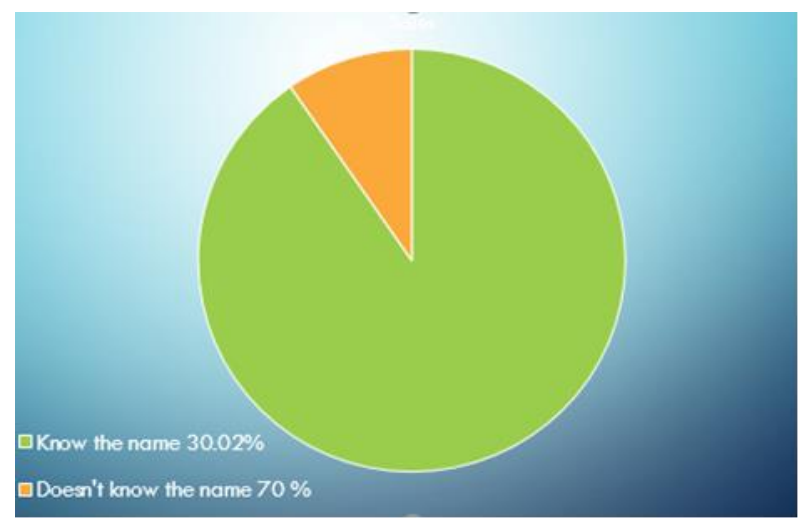

Fig 4. Chart of local people knowledge of local fish names.
The result shows that there are around 20 (twenty) fish species that are attracted to tourist and of which Clown Fish is at the top, followed by Butterfly Fish, Damsel Fish. In addition to this, only 30.02 percent of local people know the local name of those fishes.

TABLE I. The NAME OF EXotic Fishes IN The DifFERENT LANGUAGE

\begin{tabular}{|l|l|l|}
\hline \multicolumn{1}{|c|}{ Local Name } & \multicolumn{1}{c|}{ English } & \multicolumn{1}{c|}{ Latin Name } \\
\hline Ikan Nuning & Clownfish & Amphipirion Percula \\
\hline Lahaminang & Scissortail Sergant & Abudefduf Sexfasciatus \\
\hline Ikan Tampal Bor & Dusk Angelfish & $\begin{array}{l}\text { Apolemichtys } \\
\text { Xanthurus }\end{array}$ \\
\hline Ikan Poko-poko & Striped Catfish & Platidoras Armatulus \\
\hline Ikan Pipa & Trumpetfish & Aulostomus Maculatus \\
\hline Ikan Madidihang & Yellowfin Tuna & Thunnus Albacares \\
\hline Ikan Bobara & Bigeye Trevally & Caranx Sexfasciatus \\
\hline Ikan Raja Bao & $\begin{array}{l}\text { Yellowbanded } \\
\text { Sweetlips }\end{array}$ & Plectorhinchus Lineata \\
\hline Ikan Lolosi & Yellowtail Fussiler & Casio Teres \\
\hline Ikan Loa & Pufferfish \& Toby & Tetradontidae Family \\
\hline Ikan Mandahiu & Midnight Snapper & Macolor Macularis \\
\hline Ikan Gacha & $\begin{array}{l}\text { Gold Dotted } \\
\text { Sweetlips }\end{array}$ & $\begin{array}{l}\text { Plectirhinchus } \\
\text { Flavomaculatus }\end{array}$ \\
\hline Ikan Kotak/Kas & Boxfish & Ostraciidae \\
\hline Ikan Gete-gete & Pale-tail Chromis & Chromis Xanthura \\
\hline Ikan Vas & Striped Damsel & Dascyllus Melanurus \\
\hline Ikan Samasi & Cowfish & Ostriciidae Family \\
\hline
\end{tabular}

\section{CONCLUSION}

It has been revealed that the presence of a national park, including one in Bunaken island, Indonesia, comes with its advantages and disadvantages. Even though it promotes tourism at its finest, it also comes with such loss of identify, either that of the local language or that of the names of the local fish. Featuring a mixture of qualitative and quantitative research methods, this study found that the local people's knowledge upon exotic local fish is actually decreasing. It is strongly recommended that local governments, scientists, and tourism enthusiasts work together to come up with an effective solution.

\section{REFERENCES}

[1] E. Sapir E. Language and environment. American Anthropologist. Apr 1;14(2):226-42. 1912.

[2] Haugen, "The Ecology of Language" in Fill, Alwin, and peter Muhlhauser (Eds), 2001. The Ecolinguistics Reader: Language, Ecology, and Environment. Continuum. London and New York. 1972.

[3] A.V. Lindo and J. Bundsgaard (eds). Dialectial ecolinguistics three Essays for the symposium 30 years of language and ecology in Graz december 2000. Austria: University of Odense Research Group for Ecology, Language and Ecology. 2000.

[4] G. Leech. Metalanguage, pragmatics and performatives. Georgetown University Round Table on Languages and Linguistics. 1976:81-98.

[5] J.E.N. Veron. Corals of the World. No. C/593.6 V4. 2000.

[6] R.F. Myers. Micronesian Reef Fishes. A Guide to the identification of Troipcal Central and Wester Pasific. 2nd Edition. A cora; Graphics Production. 298 hal. 1991.

[7] G.R. Allen. Marine Fishes of South-east Asia. Periplus (HK) Ltd. 292p. 2000.

[8] E. Lieske and R. Myers. Reef Fishes of the World. Periplus - resived edition. Singapore. 400p. 2001. 